\title{
Identification of variables proposed for inclusion into a regional railway corridor transportation economic regulatory framework: A case of the Southern African Development Community North-South Corridor
}

\begin{tabular}{|c|c|}
\hline \multicolumn{2}{|c|}{$\begin{array}{l}\text { Authors: } \\
\text { Lubinda M. Sakanga } a^{1,2} \text { (1) } \\
\text { Erastus Mwanaumo } \\
\text { Wellington D. Thwala }{ }^{1} \text { (]) }\end{array}$} \\
\hline \multicolumn{2}{|c|}{$\begin{array}{l}\text { Affiliations: } \\
{ }^{1} \text { Faculty of Engineering and } \\
\text { Built Environment, University } \\
\text { of Johannesburg, } \\
\text { Johannesburg, South Africa }\end{array}$} \\
\hline \multicolumn{2}{|c|}{$\begin{array}{l}{ }^{2} \text { Technical and Operations } \\
\text { Department, Southern } \\
\text { African Railways Association } \\
\text { (SARA), Harare, Zimbabwe }\end{array}$} \\
\hline \multicolumn{2}{|c|}{$\begin{array}{l}\text { Corresponding author: } \\
\text { Lubinda Sakanga, } \\
\text { lubisakanga@yahoo.com }\end{array}$} \\
\hline \multicolumn{2}{|c|}{$\begin{array}{l}\text { Received: } 09 \text { Mar. } 2020 \\
\text { Accepted: } 04 \text { Aug. } 2020 \\
\text { Published: } 03 \text { Nov. } 2020\end{array}$} \\
\hline \multicolumn{2}{|c|}{$\begin{array}{l}\text { How to cite this article: } \\
\text { Sakanga, L.M., Mwanaumo, } \\
\text { E. \& Thwala, W.D., 2020, } \\
\text { 'Identification of variables } \\
\text { proposed for inclusion into a } \\
\text { regional railway corridor } \\
\text { transportation economic } \\
\text { regulatory framework: A case } \\
\text { of the Southern African } \\
\text { Development Community } \\
\text { North-South Corridor', } \\
\text { Journal of Transport and } \\
\text { Supply Chain Management } \\
\text { 14(0), a504. https://doi.org/ } \\
\text { 10.4102/jtscm.v14i0.504 }\end{array}$} \\
\hline \multicolumn{2}{|c|}{$\begin{array}{l}\text { Copyright: } \\
\text { (c) 2020. The Authors. } \\
\text { Licensee: AOSIS. This work } \\
\text { is licensed under the } \\
\text { Creative Commons } \\
\text { Attribution License. }\end{array}$} \\
\hline \multicolumn{2}{|l|}{ Read online: } \\
\hline 口佔回: & $\begin{array}{l}\text { Scan this QR } \\
\text { code with your } \\
\text { smart phone or } \\
\text { mobile device } \\
\text { to read online. }\end{array}$ \\
\hline
\end{tabular}

Background: Economic regulation involves provision of rules, systems or alteration of the allocation of resources and/or distribution of income in a manner preferred to that which could have occurred in the absence of such upheld regulations. As railway transportation continues to be recognised as an essential contributor to the economic development of many economies, because of its comparative advantage in surface transportation of bulk and heavy cargo, the competition from the road trucking and its market dominance stands as an increasing threat.

Objective: This article recommends economic factors that can be assessed for significance as variables for inclusion into a regional railway corridor transportation economic regulatory framework for enhancing competitiveness of rail operations in the Southern African Development Community (SADC) using the case of the North-South Corridor (NSC).

Method: An appraisal of economic theories and global practices are the basis used for recommending the economic factors. The different forms of corridor freight competition, the importance of property rights within the context of roles and responsibilities of railway corridor stakeholders, and the parameters determining the level of freight service are also appraised in arriving at the recommended variables.

Results: Identified variables are: corridor governance; commercial obligations of corridor parties; corridor rail service design; countering existent forms of corridor competition; and property rights allocation.

Conclusion: It is concluded that appropriate optimisation of the determined variables will enhance railway corridor economic efficiency and facilitate for the measurement of railway corridor economic competitiveness by attracting investment, pricing for freight services, predictability of operations, quality of freight service, safety and security, increasing freight market share and competition against road freight transportation.

Keywords: railway economic regulation; property rights; railway corridor market; competition.

\section{Introduction}

This article aims to contribute towards economic effectiveness in the development and use of rail transportation in meeting the aspirations of the Southern African Development Community (SADC) member states through regional transport corridors. It is meant to catalyse 'change management' in rail transport policy planning that enhances goal congruence and effectiveness of national and regional economic policies. The purpose is to improve how rail transport corridors can effectively provide the backward and forward linkages with economic sectors for their inter-dependence, growth, investment and trade facilitation, namely a railway economic regulatory framework. The article argues for practical recommendations to SADC member states, using the North-South Corridor (NSC) as a case study. The NSC has been chosen as the case study because of its geographical position and composition as it is defined by the interconnection of the railway networks amongst the Democratic Republic of Congo (DRC), Zambia, Zimbabwe, Botswana and South Africa. A transport corridor is defined as: A major regional transportation route along which a significant proportion of Member States' or nonMember States' regional and international imports and exports are carried by various transport modes, the development of which is deemed to be a regional priority. 
It therefore follows that this article identifies, based on theory, the factors that can be assessed for significance as variables to enhance the effectiveness of railway transport in facilitating trade through efficiency freight service provision. According to SADC (2012), other SADC railway corridors include the Lobito Corridor (DRC-Angola), Dar es Salaam Corridor (DRC-Zambia-Tanzania), Beira Corridor (DRC-Zambia-Zimbabwe-Mozambique), Nacala Corridor (Zambia-Malawi-Mozambique), Namibian Corridor (Namibia-South Africa), Limpopo Corridor (DRC-Zambia-Zimbabwe-Mozambique), Goba Corridor (Eswatini-Mozambique), Ressano Garcia Corridor (South Africa-Eswatini-Mozambique) and Richard's Bay Corridor (South Africa-Eswatini).

Rail transportation in the SADC region dates back to the invasion of the African continent by merchants and traders for the extraction and export of bulk and heavy commodities including minerals and agricultural produce (Olievschi 2013). Olievschi also noted that for many years, railways maintained a dominant role in transporting freight and passengers at low costs. No substantial land enabled the growth of mining and agriculture. This, however, has changed over time because of poor maintenance and operation of the railway sector in the region as a whole. According to SADC (2012), Southern Africa's rail network extends with a homogenous gauge (1067 mm [Cape Gauge]) through 12 out of 15 SADC countries. According to the SADC, this connected rail network is constrained from operating at design capacity without substantial investment in the repair and upgrading of the track and equipment, and the provision of working capital. Currently, the responsibility of maintenance and operations of the railway sector in most SADC countries has been delegated to quasi-government or parastatal institutions by respective governments since times of their independence or nationalist rule. The governments of the SADC member states and many other governments in South America and Asia, as discussed above, have the responsibility of policy development and resource mobilisation for railway infrastructure capital expenditure projects (European Investment Bank 2003). This scenario has resulted in operational challenges for the railways as they have had to maintain the entire railway infrastructure, plant and equipment from revenues generated primarily from operations. Consequences of this have been their uncompetitive pricing of their products and services in comparison to road transportation rates. In this argument however, the interests of customers and logistics value chain stakeholders to surface transport are neither fully appreciated nor contextualised. Gopa Decon International (2010), and also as recently reaffirmed by African Union Commission (2018), sees the current poor condition and performance of the SADC rail network as being primarily because of lack of maintenance and investment for both the infrastructure and the rolling stock; lack of harmonised economic regulatory standards; and also theft and vandalism of equipment. Hence, the authors realise a gap for which they recommend an effective railway economic regulatory framework to be a plausible remedy.

\section{Problem statement}

The unpredictability and unreliability problems of railway operations and service delivery on the NSC and other SADC rail transport corridors are of concern for governments, operators, customers and investors in this dynamic regional economic market.

\section{Objective}

To analyse economic characteristics of NSC rail corridor transport logistics chains relative to the market power they play and their effect on economic rents.

\section{Research questions}

- Which economic factors define economic competitiveness of the NSC rail market?

- How efficient is the allocation of economic rents in the NSC rail logistics chain and market?

The NSC railway corridor is currently run by the following railway companies operating in each respective nation: Transnet Freight Rail (TFR) (South Africa), Botswana Railways (BR) (Botswana), Beitbridge Bulawayo Railway (BBR) and National Railways of Zimbabwe (NRZ) (Zimbabwe), Zambia Railways Limited (ZRL) (Zambia) and Société Nationale des Chemins de fer du Congo (DRC).

This article uses the railway corridor case study approach to develop arguments for a regional railway transport corridor economic regulatory framework because of the economic significance of the corridor concept as defined in the SADC protocol and, more importantly, the realisation of the corridor's end-to-end significance of economic policies and regulations implemented in any of the corridor member countries. This ensues from the fact that the corridor railway network and operators have to work in a coordinated manner to facilitate both national and regional trade and socio-economic development.

Because of the above, it is important to identify the economic factors that influence the need for railway economic regulation in both developed and developing countries. This identification is guided by using applicable economic theories on the regulation and property rights theories as applicable in railway markets. Following this identification, the article thus adopts a working definition of variables as being the economic factors to be identified for use in the economic regulation of the NSC railway market and for the management of the expected externalities (including public and private sector investment, pricing of freight services, predictability of operations, quality of freight service, safety and security, increasing freight market share and competition against road freight transportation) thereof. In conclusion, 
the article argues on the deduction of railway economic regulatory theory for the NSC based on the economic characterisation of the corridor and, in turn, the variables recommended for the maximisation or minimisation of externalities thereof.

\section{Contemporary theories of economic regulation}

There are several definitions of transport regulation. In the article, the definition provided by Knemeyer, Murphy and Carroll (2018:234) is adopted because of its elaborateness. They define it as economic regulation concerning transportation means the maintaining and being in charge of all the business activities. These business acts include:

- entry of new firms in the market

- exit of the existing firms from the market

- pricing of the goods and commodities by the firms in the market

- services that are provided by the firms in the market concerning the various goods

- accounting of the firms

- financial concerns that are related to the activities of the firms in the market

- mergers, purchases and acquisitions that the firms indulge in order to expand their activities.

Transportation activities have economic significance as well as social importance. It is mandatory for government regulation to exist in order to make sure that society derives benefits from it.

In addition, this definition can be complemented with the six principles of economic regulation as stipulated by the Department of Business, Innovation and Skills of the United Kingdom (2011), which are stated as being accountability, focus, predictability, coherence, adaptability and efficiency.

A current definition of the economic regulation and the identification of the economic regulation factors are utilised to inform the testing of the hypothesis. These economic regulation factors qualify as variables for the quantitative and qualitative assessment of significance in determining the effectiveness and efficiency of the NSC railway market.

'Factor optimisation and minimisation through railway economic regulation can yield predictability of operations, return on investments and service delivery for sustainable economic development on the NSC'.

\section{Methodology for informing the variables}

The definition of a regional corridor as per the SADC protocol gives context to which economic theory should be considered in informing the impetus of particular factors to be considered as variables for inclusion in a regional railway corridor economic regulatory framework. To this end, deduction of economic regulation theory literature reviewed with rationalisation of the constitution of the NSC is the methodology applied herein. Ensuing from the contemporary definition of economic regulation and applying it to a specific sector and context approach-railway transport corridor, the article also takes into consideration the arguments of property rights theories as a means for contextualising the variables from the perspective of stakeholder portfolio influence. For completeness, an understanding of corridor market competition and its different forms is important in identification of variables for railway corridor economic regulation because of the competitive environment of transport corridors. To this end, the exposition of the different forms of railway corridor competition is considered so as to characterise the NSC railway market comprehensively.

\section{Economics theory on market regulation}

In recent times, economic regulation theories have converged into two streams, namely public interest regulation on the one hand, and private interest regulation on the other. Public interest theories of regulation are those which pronounce the need to guard against or lessen market failure distortions whilst private interest theories are those which call for free market-based demand and supply operations based on the argument that the private sector and governments have different interests and they all aspire for optimised operations as economic agents in the market. As such, the economic agents work to be costefficient and to maximise returns so that even the public interests will be served at the most economical and competitive levels in that even the private sector may offer public goods. Public interest theories of economic regulation assume that governments have sufficient information to intervene appropriately in the market whilst private interest economic regulation assumes that regulators are not sufficiently market-informed. It is on the premise of private interest theories, for example, that the Railway Association of Canada (2015) submitted a sectorspecialised opinion on the Canada Transport Act review on the basis that the sector players are better informed, understand the market demand and supply the legal requirements for railway sector economic efficiency.

Hertog (2010) reviewed economic theories of regulation from the two streams of public interest and private interest theories. In his conclusion, realising the need for huge innovative investments in most economic sectors, he posed the question as to whether regulated institutions that were found to be effective at reducing costs of operation would actually be able to meet the market that required huge innovate investments. Appreciating the exposition of his work, and also recalling the fundamentals of economic regulation theory by Smith (1910), the authors note that in a system of natural liberty, a sovereign or government only has three responsibilities to attend to. These are: (1) the duty of 
protecting the society from the violence and invasion of other independent societies; (2) the duty of protecting, as far as possible, every member of society from the injustice or oppression of every other member of it, that is, establishing an exact administration of justice and (3) the duty of erecting and maintaining public infrastructure and institutions to offer public goods that cannot be for the interest of the private sector or individual members of the society to erect or maintain.

Furthermore, on consideration of the second duty of the sovereign states arguments of property rights theorists who suggest minimising the role of the public sector, for example, Coase (1960) suggested that market failure is more often than not because of a lack of property rights, which, if specified, facilitates optimal levels of any externalities. This entails obligating role players and their understanding of the roles, responsibilities and the consequences of their action. Facilitation of this is through specified individual incentives and bargaining amongst the relevant parties. This notion is strongly attuned to private interest economic regulation.

Whilst these theories are based on a general deduction of markets, this article contextualises them in respect to the NSC railway market. In terms of the NSC, the sovereign states' responsibilities regarding regulation, as stated by Smith, are that:

- The market jurisdiction (society) is bound by one legislative authority, namely a government.

- There are other similar markets and/or substitute markets (other independent societies) within the same geographic space with the ability to serve the same customers and/or transport the same product, who can therefore penetrate the other's market.

- Players within the same market have the tendency to exploit one another.

- In every market, some services or infrastructure will not appeal to the private sector and therefore have to be provided by governments for public goods provision.

- From point (4) above, it follows that the government or private sector needs to raise funds from lucrative economic aspects for the market for re-investment into public goods provision.

Dietrich (1994) identified two critical principles from principles of economic regulation theories: firstly, that both the public sector and the private sector are involved in separate activities and have different responsibilities and secondly, that the public sector should restrict itself to developing a legal and economic infrastructure for the private sector in which to operate. However, he also argued that the public sector should remain active rather than simply responding to market failures. It is this proactiveness of the government, subject to the separate activities and different responsibilities it has from those of the private sector that this article advocates for in relation to a theory on railway economic regulation.

\section{Economic characterisation of the North-South Corridor railway market}

Following from the economic theory of regulation, the article now infers an economic characterisation of the NSC market with a view to contextualising the basis for informing the variables for inclusion into the railway economic regulatory framework. It is in this regard that it is characterised as follows:

- A corridor under multiple legal sovereign jurisdictions: It is a market composed of five sovereign states (South Africa, Botswana, Zimbabwe, Zambia and DRC) whose railway lines interconnect in the form of a chain. This chain provides freight transport services to one or more customers from one end or within the middle of the chain to another end or to a point within the chain but having to traverse other sovereign jurisdictions. One of the ends constitutes the South African ports and the other, the trade and product source markets primarily in the other four countries. The question is whether one railway economic regulatory regime can be applied to a market constituted of multiple governments. The case of the European Union (EU), where regional railways are legally committed to apply the same principles in running and managing the railways, confirms this possibility. However, the SADC regional economic community terms and conditions, which enable such a possibility, may need to be assessed for significance in regard to the NSC railway corridor market operating as a unified market.

- No multilateral commercially binding railway legislation: The NSC railway market does not have a harmonised or documented railway-specific economic regulatory regime, policy or legislation as is the case for the EU. The EU has had successive regional legislative instruments such as Directives 2012/34/EU meant to establish a single European railway market. The SADC Protocol on Transport Communications and Meteorology is the existing high-level policy document expressing the agreed aspirations of SADC member states regarding their transport corridors. Chapter 7 of the said protocol is explicit on aspirations for the regional railway markets. The SADC protocols are not legally binding. According to SARA (2018) reports, the regional railway operators currently have private bilateral commercial interchange agreements. Further to this, they also have private bilateral rolling stock leasing agreements.

- In this regard, variables for railway transport corridor economic regulation will give confidence to how the NSC rail corridor pricing is arrived at. Whether it is from the perspective of the bargaining power of the commodity shippers who have to deal with moving commodities from one end of the corridor to another via a railway network operators themselves. 
- Regionally harmonised railway gauge: Unlike the then Australian railway market, which Forsyth (1992) reported to have been adversely impacted by the lack of interstate rail harmonisation, including differing rail gauges and regulatory structures at the cost of safety and economy, the NSC railway market has the advantage of having a common Cape Gauge $(1067 \mathrm{~mm})$ across the SADC. In the case of the then Australia, the challenges of having different rail gauges from state to state include incompatibility of rail lines, equipment and operating practices; inefficiencies within the rail manufacturing industry because of failure to optimise on economies of scale; lack of sustained continuity in production and consequently reliance on foreign supplier markets; and, therefore, a compromise on local manufacturing, employment creation and sustainability. However, this article brings to light that the NSC railway market's having a common rail gauge network presents a spectrum of opportunities, which can be economically exploited. The question is how these harmonised factor opportunities can be structured as economic variables for maximisation. This calls for variable(s) that will depict corridor capacity in terms of maximum wagon load per axle, maximum number of wagons per train, turnaround time and a plausible number of trains (up and down routes) per week.

- Competition to the NSC railway corridor: The NSC railway market is faced with multiple types of competition from other SADC railway corridors, from players with the NSC railway corridor market and also from other substitute modes of transport, predominantly road freight trucks. It is this phenomenon that Smith (1910) postulated as a market requiring protection from the vulnerability of other independent markets. In addition, within the same market, there shall be plausible exploitation from other players from which the government needs to protect it. Conventionally, the NSC railway corridor is subject to the following types of railway market competition:

- Intermodal competition from road freight transporters who similarly define an alternative NSC road freight transport market.

Intermodal transport competition is currently understood as a situation in which alternative modes of transport exist between two points; in this case, corridor end-to-end points, with alternative transport modes being freight trucks and the railways. Variables that determine the market power of the alternatives and competitiveness in this regard include speed, comfort, reliability and security, amongst other customer requirements. According to the Organisation for Economic Co-operation and Development (OECD) (2003), road freight transport is preferred over rail amongst other transport modes because it offers the last mile point-to-point service, enhancing the speed of end-to-end service and reducing the need for transshipment. This minimises the risk of breakage or loss and allows for surveillance of the cargo as a unit from its origin to its destination. Whilst this argument may stand with SADC (2018) reporting a 10\% $-15 \%$ rail freight market share in the region compared to road freight $(85 \%-90 \%)$, railways argue for their absolute advantages of bulk and heavy cargo movement as a significant variable giving them capacity to deliver large volumes at once. Whilst the variables determining market power can be considered as cut-throat competition factors of consideration, the variables that give absolute advantage to the railways need assessment on how best to maximise benefits from them.

Martland (1999) argued that the primary difference between the road freight industry and the railway industry is the ease of entry and exit from the industry. Further, the road freight industry is more of a perfectly competitive industry because it presents itself as an economic model wherein competition, market entry and exit, and a generally homogeneous product work together to force rates towards the minimum long-run average variable cost. Firms that are able to produce most efficiently survive, but the less efficient do not. Martland deduced that a significant side effect of road competitiveness is that these eventual average minimum road rates stand as a constraint to rail rates. To be competitive against the road trucking transportation, the railway market needs to maximise from variables, such as those of its comparative advantage (e.g. bulk and heavier cargo carriage and delivery within one service design), which give accrual of benefits of economies of scale. The competitive nature of road freight transport has thus involuntarily forced them into a defined market realm with similar parameters of operations. The NCS railway market includes other corridors; therefore, it requires corridor-bespoke economic regulatory regimes relative to the competitive road freight industry competition. What comparative advantages to road can railway economic regulation maximise or minimise on to compete with road freight trucks?

- Corridor route-based competition: This can be explained using the example of a customer of copper from Konkola Copper Mines (KCM) in Zambia, who is desirous to transport their copper via rail to the port of Durban in South Africa. The customer will be faced with the choice of two (in other instances more) train routes between KCM and the port of Durban, that is, the Plumtree Rail Corridor (Zambia-ZRL line from Livingstone into Zimbabwe-NRZ line to Bulawayo, then into Botswana-BR to Lobatse, then into South Africa-TFR, and then to the port of Durban) and the Beitbridge Rail Corridor (ZambiaZRL line from Livingstone into Zimbabwe-NRZ line to Bulawayo, then linking to the BBR line to Beitbridge, then crossing into South Africa-TFR, and then to the port of Durban). In the event that these two lines are alike with respect to distance, reliability, security, speed, safety and comfort, then competition exists between the two routes. This is particularly 
the case between the NRZ-BBR and NRZ-BR rail sections when the collaboration between BBR and TFR and that between BR and TFR become significant. It is these variables that therefore determine the degree of competition between the two rail corridors. It is imperative to note, therefore, that the NSC rail corridor is composed of the two routes, namely Plumtree Rail Corridor and Beitbridge Rail Corridor that are in competition. The variables that determine the choice between the two need to be put into context for maximisation or minimisation.

- End-market competition: Suppose the KCM copper customer is actually interested in shipping their product to China from Zambia. This entails that the customer has alternative SADC rail corridors to use, including the NSC, the Dar es Salaam Corridor (Zambia Railways Limited [ZRL]-Tanzania-Zambia Railway Authority [TAZARA]-Dar es Salaam port) and the Beira Rail Corridor (National Railways of Zimbabwe [NRZ]-Caminhos de Ferro de Mocambique (CFM)-Beira port]), amongst others. Thereafter, the commodity is shipped from the alternative ports to China. This scenario presents multiple variables to consider. If the NSC, Beira Rail Corridor and Dar es Salaam Corridor have sufficiently similar variables in terms of cost structure, reliability, security and journey time, then their respective market powers are limited. These variables offer one scenario of variables to consider. In addition, the second scenario would be the variables determining the efficiency at the ports (Durban, Beira and Dar es Salaam) and then also the distances from the respective ports to China, including that scenario of the variables of the maritime shipping leg from the ports to China.

It is also realised that as the ports of Durban, Beira and Dar es Salaam have differing structural relationships with their respective connecting railway operators, namely TFR, CFM and TAZARA, respectively, this becomes another variable affecting the competitiveness of the corridor. This is because TFR is a company under Transnet, a holding company that also has a subsidiary company managing the port of Durban. CFM of Mozambique has the responsibility of managing the port of Beira, as well as the railways. In the case of TAZARA, which connects to Dar es Salaam port, the two are separate entities and are operated by independent companies.

Furthermore, the efficiency of the respective ports in receiving, handling, storing, loading and dispatching the product, in this case copper, onto the ships, at each of the respective ports is another extended set of variables. These variables therefore limit the extent to which each of the railway corridors can raise its price in comparison to the other corridors.

Whilst the railway industry does not have direct control over the shipping vessels transporting commodities from the SADC ports to and from the global markets, for example, China, it is nevertheless imperative that it knows the efficiency and reliability of the vessels. Also, it is important to know the travel schedules, commodity load types and the lead time of delivery between the respective ports and the global export markets.

OECD (2003) presents another illustration of end-market competition in which two rail lines, for example, the Dar es Salaam Corridor and the NSC, serve different origins (e.g. their respective ports) but the same destination (e.g. KCM for the supply of sulphur). As KCM is connected to both corridors, the market power of each of the corridors is then limited by the variable of difference in the sulphur costs from the source, as well as the added logistics costs up to their respective ports.

Railway deregulation is another form of competition that can be considered on the NSC Railway Corridor. This is competition by means of introducing multiple railway operators or separating the various functions of the integrated utility into independent legal entities. As such, railway vertical separation can be performed in different forms and at different levels. Whilst the NSC Railway Corridor currently has national vertically integrated railway systems, there is the possibility of vertical separation as experienced and practised in other regions such as in the EU, the United States (US), Japan and Australia.

\section{Feasibility of allocating property rights to the North-South Corridor railway market players}

A candid interpretation of Smith's second responsibility of a government, that is, establishing an exact administration of justice for every member of the society so as to protect them from injustice or oppression from every other member, can be postulated with appreciation of Coase's (1960) argument that market failure is more often than not because of a lack of property rights. Coase argues that the allocation of property rights for individual players in a market is through the facilitation of specified individual incentives and bargaining amongst the relevant parties.

Judging from the various types of competition to which the NSC rail market is exposed, it is important to categorically determine the corridor market players, their incentives and bargaining power in order to ascertain who needs to be catered for in terms of administrative justice.

- The first market player category includes the governments or the institution with judicial authority over the market or, in the current perspective, those who primarily own railway operators on the NSC rail market, of course within their respective jurisdictions. The exception is BBR in Zimbabwe, which is a privately owned and vertically integrated railway company running the section Bulawayo to Beitbridge. 
- The second category includes the railway operators and infrastructure managers. The NSC Corridor has a multiple number of operators; however, they are registered and authorised to operate only within their national boundaries. According to SADC (2018), the railway market on the NSC is vertically integrated under $100 \%$ government-owned parastatal companies. This is with the exception of BBR. The railway operators (TFR [South Africa], BR [Botswana], BBR and NRZ [Zimbabwe], ZRL [Zambia] and Société Nationale des Chemins de fer du Congo [DRC]) are all statutorily mandated with the responsibility to manage, operate and maintain both the rolling stock and infrastructure within their respective jurisdictions.

It is, however, imperative to note the following with regard to rolling stock operations and use on the NSC railway market, as confirmed by ZRL (2018):

- Current operations do not permit for locomotives of another railway operator to ply on another sovereign operator's rail network unless under special circumstances.

- Wagons (both loaded and empty) are allowed to cross and move on another sovereign operator's rail network, but have to be pulled by the locomotive of the operator within that jurisdiction.

- The NSC railway operators are allowed to engage in commercial leasing agreements for wagons, locomotives and other equipment such as maintenance and derailment rescue equipment from members of the corridor and also from players outside the NSC rail market.

This model of corridor operations where wagons are passed to another locomotive operator under a different jurisdiction is similar to that being practised in Russia. As Murray (2014) reported, Russian railway reform entails that the Russian Railways Holding (RZD) (Russian main rail parastatal company) maintained a monopoly on both network services, including tracks, dispatching and scheduling, and locomotives and drivers, whilst both its subsidiaries and private companies operate freight wagons and serve customers. However, for the NSC railway market, they are totally vertically integrated within their national jurisdictions except for interchanging wagons and they operate like the vertical separation reform being practised in Russia when transporting regional or international freight traffic.

- Corridor shippers or customers in respect of their expectations of the NSC rail freight transportation services are significant players. From the postulation on all types of rail competition, safety, security, speed and reliability are all essential ingredients for establishing rail market power. These are attributes that ascertain the retention of corridor customers.

Further, on rail freight commodities, as Table 1 confirms, most, if not all, rail freight commodities form part of the major export and import commodities for the economies and societies traversed by the NSC rail market. As such, it could be possible to refer to the rail freight commodities as strategic and essential economic commodities. It therefore ensues that rail freight and commodity owners, namely the customers, must have significant rights and market power. Considering the bulk and heavy nature of rail freight commodities on the NSC, as can be seen from the Table 1, a clarification on the rail market relationship between the commodity producers and commodity shippers and the rail operators and respective governments is required. This will clarify the capacity and capabilities of the NSC railway market.

\section{Commodity centrism of the North-South Corridor railway market}

Arguing further on commodity-customer power, the NSC rail market can be referred to as a rail corridor transporting or facilitating international trade of regional strategic commodities. From the Table 1, the authors realise that the

TABLE 1: Main regional import and export commodities for the North-South Corridor economies as of December 2017.

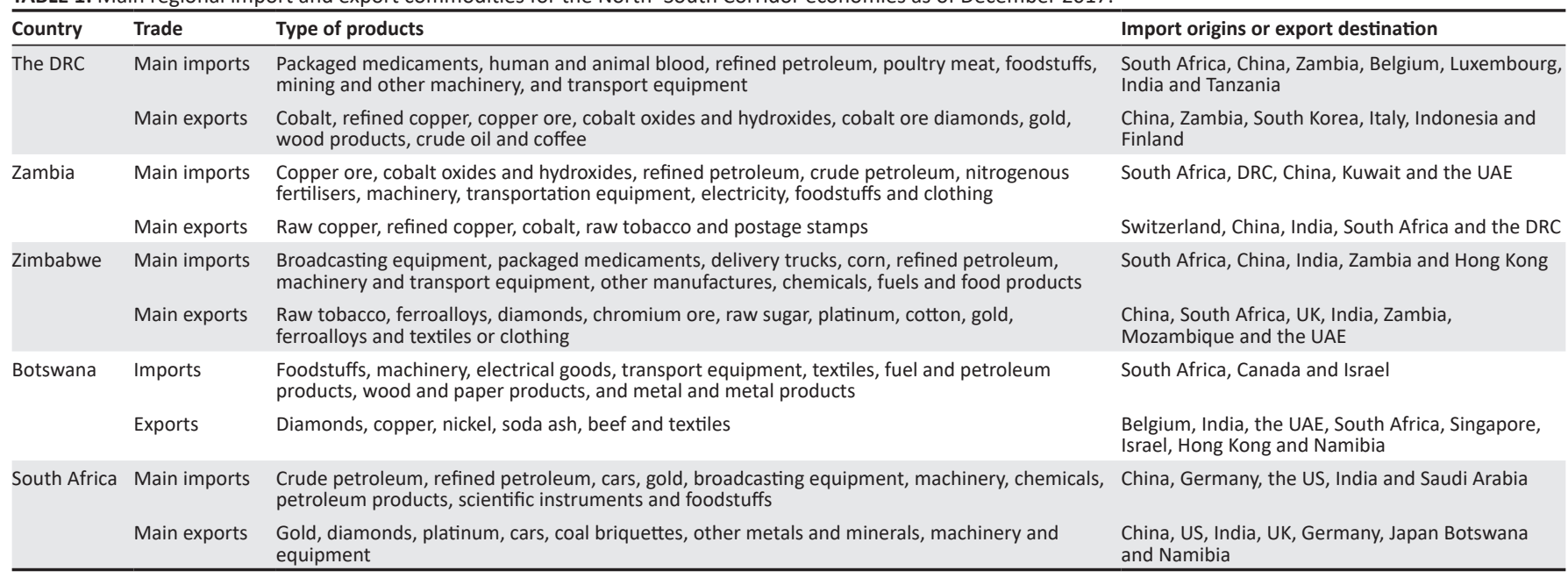

Source: Central Intelligence Agency (CIA), 2017, World fact book, viewed March 2020, from https://www.cia.gov/library/publications/the-world-factbook/.

DRC, Democratic Republic of the Congo; UAE, United Arab Emirates; UK, United Kingdom; US, United States. 
NSC railway market has the opportunity of transporting a large number of different types of freight commodities. This is because the commodities being transported via this corridor form part of or, in some instances, the main import or export commodity for the economies on this corridor. However, it is imperative for the NSC railway market to be assessed in terms of its capacity to provide freight transportation services for each of the available commodities for plausible transportation via the corridor. This is because subject to capacity, the NSC rail corridor should be capable of transporting all the main international trade commodities being imported and exported by the SADC member states composing the NSC rail market.

- Commodity origins and destinations of the rail freight have been clearly expressed as significant influencers of rail market power and competitiveness. With the knowledge of the NSC rail market freight commodities, it therefore becomes important to establish the significance of commodity origins and destinations for the determination of the economic competitiveness of the NSC rail market.

- Railway sector investors are also notable players to consider. Reading from the African Competitiveness Report by the World Economic Forum (WEF) (2017), the development of transport infrastructure has stagnated. The WEF highlights that development banks such as the African Development Bank have been encountering significant difficulties in disbursing loans and grants for infrastructure development. Stagnation of transport infrastructure and service development has been further worsened by the tighter public budgets and the banking sector liquidity; hence, there is a need for new investment solutions.

$[R]$ ecent experience in Africa shows that private- sector investment and public-private partnerships have played only a marginal role in building transport and utility infrastructure, so new models for public finance have to be found. (World Economic Forum 2017:17)

The call for railway sector investment on SADC railway corridors, including the NSC rail corridor, is further pronounced by SADC (2012) as stated below:

[A]ll the regional railway systems are operating well below their original design capacities, but are currently suffering severe capacity constraints because of poor track condition and poor locomotive and wagon availability (many units stabled). In other words, the railway systems are not able to handle more traffic without substantial investment in the repair and upgrading of track and equipment, and the provision of working capital. (p. 23)

According to Lodge et al. (2017) following their study on the Brazilian railway market, regulatory governance attracts investors for logistics infrastructure because it pronounces fundamentals including a stable policy framework for long-term planning and consistent decisionmaking; strategic capacity to develop infrastructure that goes beyond political and administrative convenience; enhanced understanding of public-private investments; regime credibility and no attitude to ad hoc renegotiation of contracts or concessions; and guidance on the resourcing of regulatory agencies.

\section{Contrast between Railway Economic Regulation and Surface Transport Regulation}

As variously argued under the different types of competition NSC rail market faces, as an addition to the aforementioned, and drawing from the recommendations by the Australasian Railway Association Inc (2005), the OECD (2003) and Sampaio et al. (2012), regulation of the railway sector cannot be separated from regulation on road or surface transport. As such, it is imperative for railway freight economic regulation to be performed with sensitivity to the road freight (trucking) markets using a comparable variable. For this reason, corridor freight tariff comparison for road and rail in respect to the commodities transported by both surface modes on the NSC Corridor is recommended for consideration as two respective variables. Whilst each SADC member state constituting the NSC may argue to have its respective rail rate to offer per commodity, a customer comparing to transport cargo by either road or rail would be considering a cumulated corridor through route as that which he would receive from the trucking industry. It is therefore proposed that a means of efficient single corridor pricing (or tariff setting) mechanism be determined for railway corridors as well. This then dictates a need for investigating into the factors determining both road and (cumulated) rail corridor tariff rates so as to enhance understanding of their comparative advantage. It is these areas of comparative advantage in corridor tariff determination that will enlighten and serve as a platform for investigation into the NSC rail market economic rents. According to WillJohnson (2006), the understanding of logistics chain market power can be better explained in terms of types of economic rents and the effects they have on the logistic chains. He substantiated his assertion with the identification of three types of economic rents, namely market power rents, Schumpeterian rents and Ricardian or resource rents. He explained that they are essentially distinguished by the type of behaviour they induce:

- Market power rents: This is taken to refer to the monopolistic or competitiveness of the logistics chain operations, especially the rail.

- Schumpeterian rents: These are 'transient surplus earnings above the costs necessary to deploy and use a resource. They emerge in the process of creative destruction in markets and result from new combinations of resources (including new modes of organization) that entrepreneurs initiate' (Schumpeter 1934).

- Perez (1983) postulated that collative innovative activity forces socio-economic change that determines long-run economic evolution. As such, Schumpeterian rents may arise from incremental innovations, radical innovations, and change in technology systems 
combining incremental and radical innovations, and also through techno-economic paradigm shifts. Further, Freeman and Perez (1988) resolved that the new techno-economic paradigm is not only about new products and productivity systems, but essentially also involves having potential for use in pertaining to market environments, being characterised by elastic log-run supply conditions and, most importantly, facilitating cost reductions and therefore the overall cost of doing business.

- Ricardian rents: According to Ricardian theory, economic rents on land are the value of the difference in productivity between a given piece of land and the poorest piece of land (or the land most distant from the market), that is, producing the same goods (bushels of wheat) under the same conditions (of labour, capital, technology and climate) (Ricardo 1821).

\section{Conclusion}

In this article, the concise appreciation of economic regulation relative to railway transport corridor markets has provided critical insights into the fundamental variables recommendable for characterising a railway economic regulatory framework. Principles of economic regulation theory and applicability were extended from focusing on a nation's economic market to the practicality of a regional railway economic market constituted by sovereign national railway sections interconnected along a railway corridor that, in most instances, aspires to serve freight customers as a seamless railway network from one end to another.

Because of the aforementioned, the article has inferred an economic characterisation of the NSC railway market relative to the fundamentals of economic regulation theory as postulated. It has been deduced that the NSC railway market can currently be characterised as follows:

- Characteristic 1: The market is governed under multiple (sectional or national) legal sovereign jurisdictions.

- Characteristic 2: The market has no multilateral commercially binding railway legislation or agreement.

- Characteristic 3: The market is advantaged to have a regionally harmonised railway gauge.

- Characteristic 4: The market is exposed to different forms of competition.

From these four theoretically inferred characteristic features of the NSC railway market, analysis of each has informed the variables for inclusion into a regional railway economic regulatory framework. The variables recommended per characteristic are summarised below:

Characteristic 1: Variables on governance under multiple legal sovereign jurisdictions:

- degree of unification of the railway corridor market subject to terms and conditions of SADC member states.
Characteristic 2: Variables on multilateral corridor commercially binding railway legislation:

- corridor pricing (including cumulative railway corridor tariff rate and the competing trucking industry corridor rate for the same freight commodity)

- corridor customer service level agreements

- commodity or customer centrism

Characteristic 3: Variables on areas of rail comparative advantaged of having a regionally harmonised railway gauge:

- maximum wagon load

- maximum number of wagons per train

- corridor turnaround time

- plausible number of trains (up and down routes) per week

Characteristic 4: Variables on different forms of competition:

- intermodal transport competition variables for comparison (speed, reliability and security, amongst other customer requirements)

- intermodal transportation competition variables on absolute advantage (e.g. bulk and heavy cargo carriage capacity by railways vs door-to-door delivery by trucks)

- corridor route-based competition variables

- end-market competition variables

- deregulation (introduction of multiple corridor operators) versus regulation - corridor operational capacity expansion options

It is recommended that qualitative and quantitative data be collected on these variables using a structured questionnaire relative to the four areas of railway transport corridor characterisation. This is to analyse for the determination of their statistical significance on testing the hypothesis: Factor optimization and minimization through railway economic regulation can yield predictability of rail operations, return on investments and service delivery for sustainable economic development on a regional corridor for example, the North South Corridor.

Upon testing the hypothesis, an informed construct of a regional railway transport economic regulatory framework shall be determined with the constituting variables identified.

The inferred characteristics above may collectively be unique and representative of the SADC and NSC railway market in particular. However, if considered is carried out bespoke to another particular railway corridor, that is, characteristic by characteristic, other economic regions and federal states such as the EU, Australia, Russia, Japan and America, amongst others, it is probable to find some similarities, but also peculiar differing situational differences. As different regions and countries continue to attempt different methods of enabling their railway efficiency and economy efficacy by employing various and varying economic regulatory initiatives, each of these areas of characterisation then becomes better informed subject to prevailing circumstances. This therefore brings us to a realisation that the four characteristics may be influenced by political, economic, social, technological, environmental and 
legal (PESTEL) factors. It is therefore recommended for the next stage of this research that an elaborate investigation into the importance of PESTEL factors on railway economic regulation be undertaken.

Furthermore, this will also give further appreciation to the argument for logistics chain economic rents that may accrue from different stimuli and conditions. These include Schumpeterian rents, Ricardian rents and market power rents. Such that the expectation of attracting and managing for the desired externalities include public and private sector investment, competitive pricing of freight services, predictability of operations, quality of freight service, safety and security, increasing freight market share and competition against road freight transportation.

In addition to the above-identified characteristics of the NSC railway market, the article has also established the market players who can rightly be termed stakeholders of a railway transport economic regulatory framework because of their identified stake, namely the roles, responsibilities and expectations from them with regard to their economic role in the railway market. This was conducted in the context of arguing for the feasibility of allocating property rights to the different role players in the NSC railway market. The allocation and weighting of these property rights to the identified players becomes an essential tier proposed to characterise the railway economic regulatory framework. These have been profiled to include governments or institutions with judiciary authority over the market; railway operators, infrastructure managers, corridor shippers or customers, commodity peculiarities, origins and destinations and railway investors. It is therefore recommended that the data collection tool, as suggested above, includes a respective section for collection of data on stakeholders with economic property rights on a regional railway transport corridor, as a means informing a bespoke railway economic regulation.

Upon having informed the variables recommended for inclusion in a railway transport economic regulatory framework for a regional corridor, it is further recommended that the same variables be considered for use in assessment of the economic effectiveness, efficiency and feasibility of existing regional or planned regional railway corridors, thus serving as a structured railway corridor economic feasibility assessment tool.

\section{Acknowledgements}

My wife Viviane Sakanga and our children Nali, Thabo and Palisa, and the work of the Southern African Railways Association and the SADC Secretariat are applauded for inspiring this work.

\section{Competing interests}

The authors have declared that no competing interests exist.

\section{Authors' contributions}

All authors contributed equally to this work.

\section{Ethical consideration}

The authors confirmed that ethical clearance was not required for the study

\section{Funding information}

This research did not receive any specific grant from funding agencies in the public, commercial or not-for-profit sectors.

\section{Data availability statement}

Data sharing is not applicable to this article as no new data were created or analysed in this study.

\section{Disclaimer}

The views and opinions expressed in this article are those of the authors and do not necessarily reflect the official policy or position of any affiliated agency of the authors.

\section{References}

African Union Commission, 2018, Vision 2063 Africa integrated high speed railway network and master plan, AUC Secretariat, Addis Abba.

Australasian Railway Association, 2005, A Single National Land Transport Economic Regulator, Kingston.

Central Intelligence Agency (CIA), 2017, World fact book, viewed March 2020, from https://www.cia.gov/library/publications/the-world-factbook/.

Coase, R.H., 1960, 'The problem of social cost', in Gopalakrishnan, C. (ed.), Classic Papers in Natural Resource social cost. Journal of Law and Economics, pp. 26-27, Palgrave Macmillan, London, https://doi.org/10.1057/9780230523210_6

Dietrich, M., 1994, Transaction cost economics and beyond: Towards a new economics of the firm, Routledge, London.

Department of Business, Innovation and Skills of the United Kingdom, 2011, Principles of Economic Regulation, London.

European Investment Bank - MateuTurro, 2003, Railway Project Appraisal Guidelines. Adopted by UN-ECE.

Forsyth, P., 1992, Transport deregulation in Australia: An interpretation in terms of public interest and private interest theories, Australian National University, Canberra.

Freeman, C. \& Perez, C., 1988, 'Structural crisis of adjustment: Business cycles and investment behaviour', in Dosi et al. (eds.), Journal of economic literature, pp. 38-66, Francis Pinter, London. https://www.scirp.org/reference/ReferencesPapers. aspx?Referencel $\mathrm{D}=191258$

Gopa Decon International, 2010, Revised RIDMP first draft: Annexure 5.2: Transport - Corridors and border posts, Gopa Study Report to SADC, Gaborone.

Hertog, J.D., 2010, Review of economic theories of regulation, University of Utrecht, Utrecht.

Knemeyer, M., Murphy, P.R. \& Carroll, J.A., 2015, Contemporary logistics, 11th edn., Ohio State University, Pearson, Harlow.

Lodge, M., Stolk, V.C., Machado, J.B., Schweppenstedde, D. \& Stepanek, M., 2017 Regulation of logistics infrastructure in Brazil, RAND Corporation, Santa Monica, CA, viewed 30 June 2020, from https://www.rand.org/t/RR1992.

Martland, C.D., 1999, 'Productivity and prices in the U.S. rail industry: Experience from 1965 to 1995 and prospects for the future', Journal of the Transportation Research Forum 38(1), 21

Murray, B., 2014, Russian railway reform programme, Working Paper, European Bank, Prepared in June 2014 London EC2A 2JN, UK.

Olievschi, V.N., 2013, Rail transport: Framework for improving railway sector performance in sub-Saharan Africa, Sub Saharan Africa Transport Policy Project (SSATP), Washington.

Organisation for Economic Co-operation and Development (OECD), 2003, Railway reform in China: Promoting competition, Global Relations Secretariat, Paris.

Perez, C., 1983, 'Structural change and the assimilation of new technologies in the economic and social systems', Futures 15(5), 357-375. https://doi.org/10.1016/ 0016-3287(83)90050-2 
Railway Association of Canada, 2015, Canada Transportation Act Review, Railway Association of Canada, Ottawa.

Ricardo, D., 1821, On the principles of political economy and taxation, 3rd edn., Batoche Books, Kitchner 2001, ON.

Sampaio, P., Dutra, J., Gonçalves, E., Daychoum, M. \& Palermo, B., 2012, 'Regulatory reform in the Brazilian railway sector - A preliminary assessment', in Proceeding of the 4th Conference on the Regulation of Infrastructures, Florence, 12 June.

Schumpeter, J.A., 1934/2008, The theory of economic development: An inquiry into profits, capital, credit, interest and the business cycle, transl. from the German by R. Opie, Transaction Publishers, London.

Smith, A., 1910, The wealth of nations, vol. 2, J.M. Dent \& Sons, London.

Southern Africa Development Community (SADC), 1996, Protocol on Transport Communications and Meteorology, Signed 24 August 1996, Maseru, Lesotho.
Southern African Development Community (SADC), 2012, Transport sector plan - SADC regional infrastructure development master plan, SADC, Tshwane, SA.

Southern African Railways Association (SARA), 2018, 'First Quarter Southern African Railways corridor performance', Report on SADC Railway 2018, SARA headquarters, Harare.

Wills-Johnson, N., 2006, Economic regulation of Railways in logistics chains: A problem looking for a solution or a solution looking for a problem? Planning and Transport Research Centre (PATREC), Perth

World Economic Forum 2017, African Competitiveness Report 2017, Viewed FebruaryMarch 2020, from https://www.weforum.org/reports/africa-competitivenessreport-2017.

Zambia Railways Limited (ZRL), 2018, Zambia Railways strategic plan, Viewed JuneOctober 2019, from http://zrl.com.zm/wp-content/uploads/2019/07/ZRL-FinalStrategic-Business-Plan-2018-22-Final-Approved-Version.pdf. 